\title{
Prediction Of Mortality By Pediatric Risk Of Mortality (PRISM) III Score In NGMC Pediatric Intensive Care Unit \\ $\mathrm{Km} \mathrm{R}$
}

\begin{abstract}
Background: The pediatric risk of mortality (PRISM) III score helps in predicting prognosis. It is being used in most of the pediatric intensive care units of developed world and few of developing ones. We have undertaken this study to evaluate efficacy of PRISM IIIscore in prediction of mortality. Material and Methods: Prospective hospital based analytical study conducted from May 2018 to April 2019 in patients admitted to pediatric intensive care unit (PICU) of NGMC, Nepal. The pediatric risk of mortality score (PRISM) III which includes 14 parameters (physiological and laboratory) was recorded within 24 hours of admission. A total of 480 patients were included. The final outcome was recorded as death or discharge. Result: It was observed that mortality increased with increasing PRISM III score approaching almost $100 \%$ by PRISM III score of 25 and more. The variables that were found to be risk factors for death were readmission, diseases of hepatobiliary system, mechanical ventilation (MV) and use of vasoactive drugs with $p$ value of $<0.001$. PRISM III score offers a good discriminative power with $0.866(95 \% \mathrm{Cl})$ area under the ROC curve. Conclusion: The pediatric risk of mortality score was found to be a useful tool for prediction of prognosis.
\end{abstract}

Keywords: Pediatric risk of mortality score, mortality, pediatric intensive care unit

\section{INTRODUCTION}

The pediatric intensive care unit facilities are improving for last few years in different parts of our country with opening and improvement of the pediatric intensive care units. The outcome of the patients admitted to PICU is not widely reported in Nepal, despite the necessity to know the scope of improvement and work on it, need of more advanced equipment and aggressive treatment of critically ill children of units being known. Reduction of mortality is the basic aim of PICU. Estimation of mortality risk predictions by pediatrician is highly subjective. ${ }^{1}$ Therefore there is need of a scoring system to predict risk of mortality of patients admitted to PICU. PRISM III score is very useful in estimating the risk of mortality, prognosis and to evaluate quality of care. It also helps selection of appropriate treatment modality, ethical and economic issues. PRISM III score is one of the main indicators used in PICU. There are 14 parameters (physiological and laboratory) and each parameter records highest severity value in first 24 hours. ${ }^{2}$ The aim of present study is the prediction of mortality rate in PICU by application of PRISM III score.

To improve the quality of care in PICU, it is very important to have a constant relationship between test parameters and

\footnotetext{
Corresponding Author:

Dr. Roma Bora

Assistant Professor

Department of Pediatrics,

Nepalgunj Medical College, Teaching Hospital

Nepalgunj, Banke,

E-mail: bora.roma@gmail.com
}

outcome of patients. The PRISM score has been developed and validated in most of the PICUs of developed countries and there are very few reports from some developing countries ${ }^{1,3,4}$. Google search using term "PRISM III scoring in Nepal" did not show any study done in Nepal. Expertise of health personal managing PICUs varies depending upon their experience and training. PICUs are managed by pediatric consultants, residents, nurses who have different subjective perceptions of score to be given. There are some reports from India which support usefulness of PRISM III score for prediction of prognosis $^{3,4}$.

\section{MATERIALS AND METHODS}

This is a prospective hospital based study conducted at the PICU of Nepalgunj Medical College, Nepalgunj catering to critical care needs of 500-600 children per year from 1 month to 15 years of age. This study was conducted over a period of 1 year from May 2018 to April 2019. During the study period a total of 480 cases were enrolled in the study. Readmission was taken as separate admission. PRISM III score was calculated for all the patients within 24 hours of admission. Pediatric cases aged between 1 month and 15 years admitted directly to PICU were included in the study. Patients not giving consent to be enrolled in the study, death occurring within first 10 hours of PICU admission, case which were discharged from PICU within 24 hours of admission, patient requiring continuous CPR and not being stable for $\geq 2$ hours and patients who left against medical advice were excluded from the study.

The study design was approved by the Institution's Ethical review committee. Written and informed consent was taken from the guardian of patients. The information collected on each PICU admission included name, age, requirement of 
ventilator, PICU stay, diagnosis, outcome (survived or not). Necessary investigations were done as per need. PRISM III score was calculated within 24 hours of admission in PICU. Calculation of PRISM III score was done as per recommendation of Pollack et al ${ }^{5}$. Total PRISM III score was calculated for every patient by summing of all the sub scores within 24 hours of admission. The data was analyzed by SPSS version 20.

\begin{tabular}{|c|c|c|c|}
\hline Variables & Age restric & ns and Range & Score \\
\hline $\begin{array}{l}\text { Systolic blood } \\
\text { pressure in } \\
\mathrm{mmHg}\end{array}$ & $\begin{array}{l}\text { Infants } \\
130-160 \\
55-65 \\
>160 \\
40-54 \\
<40\end{array}$ & $\begin{array}{l}\text { Children } \\
50-200 \\
65-75 \\
>200 \\
50-64 \\
<50\end{array}$ & $\begin{array}{l}2 \\
6 \\
7\end{array}$ \\
\hline $\begin{array}{l}\text { Diastolic Blood } \\
\text { pressure in } \\
\mathrm{mmHg}\end{array}$ & $\begin{array}{l}\text { All ages } \\
>110\end{array}$ & & 6 \\
\hline $\begin{array}{l}\text { Heart rate in } \\
\text { beats per minute }\end{array}$ & $\begin{array}{l}\text { Infants } \\
>160 \\
<90\end{array}$ & $\begin{array}{l}\text { Children } \\
>150 \\
<80\end{array}$ & $\begin{array}{l}4 \\
4\end{array}$ \\
\hline $\begin{array}{l}\text { Respiratory rate } \\
\text { in breaths per } \\
\text { minute }\end{array}$ & $\begin{array}{l}\text { Infants } \\
61-90 \\
>90 \\
\text { Apnea }\end{array}$ & $\begin{array}{l}\text { Children } \\
51-70 \\
>70 \\
\text { Apnea }\end{array}$ & $\begin{array}{l}1 \\
5 \\
5\end{array}$ \\
\hline $\mathrm{PaO2} / \mathrm{FiO2}$ & All ages & $\begin{array}{l}200-300 \\
<200\end{array}$ & $\begin{array}{l}2 \\
3\end{array}$ \\
\hline $\begin{array}{l}\text { PaCO2 in } \\
\text { torr }(\mathrm{mmHg})\end{array}$ & All ages & $\begin{array}{l}51-65 \\
>65\end{array}$ & $\begin{array}{l}1 \\
5\end{array}$ \\
\hline $\begin{array}{l}\text { Glasgow coma } \\
\text { score }\end{array}$ & All ages & $<8$ & 6 \\
\hline $\begin{array}{l}\text { Pupillary } \\
\text { reactions }\end{array}$ & All ages & $\begin{array}{l}\text { Unequal or } \\
\text { dilated } \\
\text { Fixed and dilated }\end{array}$ & $\begin{array}{l}4 \\
10\end{array}$ \\
\hline PT/ PTT & n'1 - . & $1\ulcorner+: \ldots \ldots+\ldots+\cdots-1$ & 1 \\
\hline $\begin{array}{l}\text { Total bilirubin } \\
\mathrm{mg} / \mathrm{dL}\end{array}$ & $>1$ month & $>3.5$ & 6 \\
\hline $\begin{array}{l}\text { Potassium in } \\
\mathrm{mEq} / \mathrm{L}\end{array}$ & All ages & $\begin{array}{l}3.0-3.5 \\
6.5-7.5 \\
<3.0 \\
>7.5\end{array}$ & $\begin{array}{l}1 \\
1 \\
5 \\
5\end{array}$ \\
\hline $\begin{array}{l}\text { Calcium in } \\
\mathrm{mg} / \mathrm{dL}\end{array}$ & All ages & $\begin{array}{l}7.0-8.0 \\
12.0-15.0 \\
<7.0 \\
>15.0\end{array}$ & $\begin{array}{l}2 \\
2 \\
6 \\
6\end{array}$ \\
\hline $\begin{array}{l}\text { Glucose in } \\
\mathrm{mg} / \mathrm{dL}\end{array}$ & All ages & $\begin{array}{l}40-60 \\
250-400 \\
<40 \\
>400\end{array}$ & $\begin{array}{l}4 \\
4 \\
8 \\
8\end{array}$ \\
\hline $\begin{array}{l}\text { Bicarbonate in } \\
\mathrm{mEq} / \mathrm{L}\end{array}$ & All ages & $\begin{array}{l}<16 \\
>32\end{array}$ & $\begin{array}{l}3 \\
3\end{array}$ \\
\hline
\end{tabular}

Table I: PRISM III score Pollack et al.5

\section{RESULTS}

During the study period 531 cases were admitted in the Pediatric Intensive Care Unit from May 2018 to April 2019 out of which only 480 cases met inclusion criteria and hence were enrolled in the study. The mean age was found to be $39 \pm 47$ months and mean duration of PICU stay was $56 \pm 44$ hours. There were 317 males and 163 females; mortality among different sexes was not statically significant ( $P$ value 0.175 ). The majority of patients were clinical $(98.5 \%)$ and the most common cause of death was the diseases of respiratory system (38.8\%). Mechanical ventilation and vasoactive drugs were required in $22.5 \%$ and $23.1 \%$ cases respectively. Mortality was $9.2 \%$. The characteristics of the study population are detailed in Table II. Mortality associated with PRISM score of expired and survived patients is detailed in table III. The variables that were found to be risk factors for death were readmission, diseases of hepatobiliary system, mechanical ventilation (MV) and use of vasoactive drugs with $p$ value of $<0.001$. Variables found to be risk factors of death are given in table IV. PRISM III score in our center offers a good discriminative power with $0.866(95 \% \mathrm{Cl})$ area under the ROC curve. This area under the curve is an expression of the overall accuracy of a model in differentiating outcome groups and is a good measure of its

predictive ability. Inspecting the ROC curve, cut off point 15 was found to be appropriate to predict mortality so taking 15 as cut off point the sensitivity was $72.7 \%$ and specificity was $91.1 \%$.

\begin{tabular}{|c|c|c|}
\hline Variables & N (\%) & $\ldots$ \\
\hline Total patients & 480 & \\
\hline Age (months) & & $\ldots \ldots$ \\
\hline $\begin{array}{l}\text { Length of PICU stay } \\
\text { (hours) }\end{array}$ & & $56 \pm 44.182$ \\
\hline $\begin{array}{l}\text { Gender } \\
\text { Male } \\
\text { Female }\end{array}$ & $\begin{array}{l}317(66) \\
163(34)\end{array}$ & \\
\hline $\begin{array}{l}\text { Patients } \\
\text { Clinical } \\
\text { Surgical }\end{array}$ & $\begin{array}{l}473(98.5) \\
7 \quad(1.5)\end{array}$ & \\
\hline $\begin{array}{l}\text { Underlying disease } \\
\text { Central Nervous System } \\
\text { Respiratory System } \\
\text { Hepatobiliary } \\
\text { Infectious disease } \\
\text { Hematological disease } \\
\text { Renal disease } \\
\text { Gastrointestinal disease } \\
\text { Cardiovascular disease } \\
\text { Others }\end{array}$ & $\begin{array}{l}160(33.3) \\
186(38.8) \\
11(2.3) \\
42(8.8) \\
31(6.5) \\
10(2.1) \\
9(1.9) \\
12(2.5) \\
19(4)\end{array}$ & \\
\hline
\end{tabular}




\begin{tabular}{|c|c|c|}
\hline $\begin{array}{l}\text { Use of mechanical } \\
\text { ventilation }\end{array}$ & $108(22.5)$ & \\
Yes & $372(77.5)$ & \\
No & $111(23.1)$ & \\
Yes & $369(76.9)$ & \\
No & $44(9.2)$ & \\
\hline $\begin{array}{c}\text { Use of vasoactive drugs } \\
\text { Deaths }\end{array}$ \\
\hline
\end{tabular}

Table II -Characteristics of study population

\begin{tabular}{|l|l|l|l|l|}
\hline $\begin{array}{l}\text { PRISM } \\
\text { III } \\
\text { Score }\end{array}$ & Death & Survival & Total & $\begin{array}{l}\text { Observed } \\
\text { morality } \\
\text { (\%) }\end{array}$ \\
\hline $0-4$ & 5 & 151 & 156 & 3.2 \\
\hline $5-9$ & 2 & 175 & 177 & 1.1 \\
\hline $10-14$ & 5 & 71 & 76 & 6.6 \\
\hline $15-19$ & 5 & 25 & 30 & 16.7 \\
\hline $20-24$ & 3 & 10 & 13 & 23.1 \\
\hline $25-29$ & 6 & 2 & 8 & 75 \\
\hline $30-34$ & 5 & 2 & 7 & 71.4 \\
\hline $35-39$ & 5 & 0 & 5 & 100 \\
\hline $40-44$ & 4 & 0 & 4 & 100 \\
\hline $45-49$ & 4 & 0 & 4 & 100 \\
\hline
\end{tabular}

Table III-PRISM comparison between expired and survived patients

\begin{tabular}{|c|c|c|c|}
\hline Variable & Category & $\begin{array}{l}\text { Deaths } \\
\text { n (\%) }\end{array}$ & $p$ \\
\hline Age (months) & $\begin{array}{l}1-12 \\
13-60 \\
61-180\end{array}$ & $\begin{array}{c}24(10.7) \\
12(7.6) \\
8(8.2)\end{array}$ & 0.540 \\
\hline $\begin{array}{l}\text { Length of PICU } \\
\text { stay (hours) }\end{array}$ & $\begin{array}{l}25-72 \\
73-168 \\
>168\end{array}$ & $\begin{array}{l}40(10.5) \\
4(4.5) \\
0(0)\end{array}$ & 0.116 \\
\hline Gender & $\begin{array}{l}\text { Male } \\
\text { Female }\end{array}$ & $\begin{array}{l}25(7.9) \\
19(11.7)\end{array}$ & 0.175 \\
\hline Patients & $\begin{array}{l}\text { Clinical } \\
\text { Surgical }\end{array}$ & $\begin{array}{l}44(9.3) \\
0(0)\end{array}$ & 0.397 \\
\hline Readmission & $\begin{array}{l}\text { Yes } \\
\text { No }\end{array}$ & $\begin{array}{l}5(55.6) \\
39(8.3)\end{array}$ & $<0.001$ \\
\hline $\begin{array}{l}\text { Underlying } \\
\text { disease }\end{array}$ & $\begin{array}{l}\text { Central Nervous System } \\
\text { Respiratory System } \\
\text { Hepatobiliary } \\
\text { Infectious disease } \\
\text { Hematological disease } \\
\text { Renal disease }\end{array}$ & $\begin{array}{l}9(5.6) \\
18(9.7) \\
5(45.5) \\
5(11.9) \\
3(9.7) \\
0(0)\end{array}$ & $<0.001$ \\
\hline
\end{tabular}

\begin{tabular}{|l|l|l|l|} 
& $\begin{array}{l}\text { Gastrointestinal disease } \\
\text { Cardiovascular disease } \\
\text { Others }\end{array}$ & $\begin{array}{l}0(0) \\
3(25)\end{array}$ & \\
& $1(5.3)$ & \\
\hline $\begin{array}{l}\text { Use of } \\
\text { mechanical } \\
\text { ventilation }\end{array}$ & Yes & $35(32.4)$ & $<0.001$ \\
\hline $\begin{array}{l}\text { No of } \\
\text { vasoactive } \\
\text { drugs }\end{array}$ & No & $9(2.4)$ & \\
\hline
\end{tabular}

Table IV -Risk factors for death

\begin{tabular}{|l|l|l|}
\hline Patient & PRISM Mean & p \\
\hline Expired & 25.20 & $<0.001$ \\
\cline { 1 - 2 } Survived & 7.27 & \\
\hline
\end{tabular}

Table V - PRISM comparison between patients who died and survived

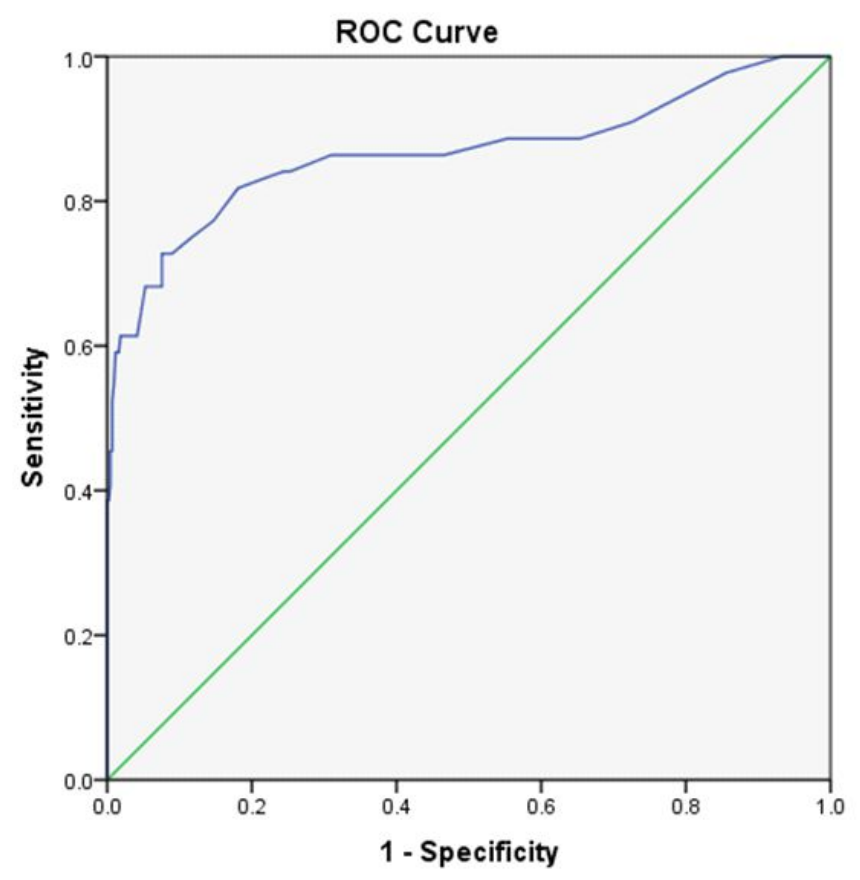

Diagonal segments are produced by ties.

Figure 1: ROC curve for prism score area under curve $=0.866$

\begin{tabular}{|l|l|}
\hline Area under the ROC curve (AUC) & 0.866 \\
\hline Standard Error & 0.039 \\
\hline 95\% Confidence interval & $0.790-0.942$ \\
\hline Significance level P & $<0.001$ \\
\hline
\end{tabular}




\section{DISCUSSION}

Response to an insult differs in different individuals so recovery from illness also varies in different individuals. Prediction of outcome of patients admitted to PICU helps in formulating policy and optimum use of limited resources of the country. Intent of pediatric intensive care unit is to improve quality of care and to reduce the morbidity and mortality. PRISM III score helps in prediction of morality risk by changes of normal physiological values during diseased state. This was designed by Pollack et al. in $1996^{5}$. Various studies have shown PRISM III score to be a good predictor of mortality risk assessment. At our center we found the mortality of $9.2 \%$ which is low in comparision to studies ${ }^{6.8}$ and is more as compared to studies. ${ }^{9 \cdot 11}$ Bilan et al ${ }^{12}$ found mortality of $9.05 \%$ in their study done in Pakistan which is similar to ours. We found that as the PRISM score increases mortality also increases and this fact is supported by various Indian, Asian and other studies ${ }^{6,7,9,10,12,13,14}$. There was no significant gender difference in mortality in our study. Costa et al ${ }^{15}$ also found no gender difference for mortality whereas Aragao et $\mathrm{al}^{16}$ found mortality to be more in males. The use of mechanical ventilation and vasoactive drugs were found to be risk factors for death, corroborating the findings of other authors who also showed a higher mortality rate in patients undergoing these procedures ${ }^{16,17}$. PRISM III score of $\geq 25$ was associated with very high mortality in our study. Martha et a $\mathrm{a}^{18}$ and several other studies ${ }^{19,20}$ also reported higher mortality with higher PRISM scores. Shann et $\mathrm{al}^{21}$ stated that if the area under the curve of ROC is equal to one, the model is perfect. An area between 0.9 and $0.99 \%$ is very good, between 0.8 and $0.89 \%$ is good and finally, between 0.7 and $0.79 \%$ is acceptable. If the area is 0.5 , the model is bad. In our study, the area under the curve was $86.6 \%$, so it is good to predict mortality in patients admitted to PICU. Khajeh A et $\mathrm{al}^{22}$ reported area under the curve to be $80 \%$ which is similar to our study.

\section{CONCLUSION}

The mortality increases with increasing PRISM III score. PRISM III score offers a good discriminative power in prediction of mortality with $0.866(95 \% \mathrm{Cl})$ area under the ROC curve. In our study variables found to be risk factors for death were readmission, diseases of hepatobiliary system, mechanical ventilation (MV) and use of vasoactive drugs.

Acknowledgement: The author is grateful to Mr. Gaurav Jung Shah, Assistant Professor, Department of Community Medicine for helping in statistical analysis.

\section{REFERENCES}

1. Taori RN,Lahiri KR, Tullu MS. Performance of PRISM (pediatric risk of mortality) score and PIM (pediatric index of mortality) score in a tertiary care pediatric ICU. Indian J Pediatr.2010;77(3):267-71.
2. Pollack MM, Ruttimann E, Getson PR. Pediatric risk of mortality (PRISM) score. Crit Care Med. 1988;16:111016.

3. Singhal D, Kumar N, Puliyel JM, Singh SK, Srinivas V. Prediction of mortality by application of PRISM score in intensive care unit. Indian Pediatr. 2001;38(7):714-7.

4. Bellad R, Rao S,Patil VD, Mahantshetti NS. Outcome of intensive care unit patients using pediatric risk of mortality (PRISM) score. Indian Pediatr. 2009;46(12):1091-2.

5. Pollack MM, Kantilal MP, Ruttimann. PRISM III: An updated pediatric risk of mortality Score. Crit Care Med 1996; 24:743-752.

6. Bhatia RC, Singh D, Gautam A, Pooni PA, Shimar TS. NCPCC 2005 - Conference Abstracts. Pediatric Oncall. 2006;5:3.

7. Ponce AL. Simplified PRISM III score and outcome in the pediatric intensive care unit. Pediatr Intern. 2005;47:803.

8. Varma A, Damke S, Meshram R, Vagha J, Kher A, Vagha K. Prediction of mortality by pediatric risk of mortality (PRISM III) score in teriary care rural hospital in India. Int J ContempPediatr. 2017 Mar;4(2):322-7.

9. Brady AR, Harrison D, Black S, Jones S, Rowan K, Pearson $\mathrm{G}$. Assessment and optimization of mortality prediction tools for admissions to pediatric intensive care in the United Kingdom. Pediatr. 2006;117:733-42.

10. Gemke RJ, Van VJ. Scoring systems in pediatric intensive care: PRISM III versus PIM. Intensive Care Med. 2002;28(2):204-7.

11. Slater $A$, Shann $F$. The suitability of the pediatric index of mortality (PIM), PIM2, the pediatric risk of mortality (PRISM), and PRISM III for monitoring the quality of pediatric intensive care in Australia and New Zealand. PediatrCritCare Med. 2004;5(5):447-54.

12. Choi KMS, DanialKN, Wong SF, Kwok KL, Chow PY.Assessment of the pediatric index of mortality (PIM) and the pediatric risk of mortality (PRISM) III score for prediction of mortality in a Pediatric intensive care unit in Hong Kong. Hong Kong Med J. 2005;11:97-103.

13. Bilan N, Galehgolab BA, Emadaddin A, Shiva SH. Risk of mortality in pediatric intensive care unit, assessed by PRISM-III. Pak J Biol Sci. 2009;12:480-5.

14. Tan GH, Tan TH, Goh DYT, Yap HK. Risk factors for predicting mortality in a pediatric intensive care unit. Ann Acad Med Singapore. 1998;27:813-8.

15. Costa GA, Delgado AF, Ferraro A, Okay TS. Application of the Pediatric Risk of Mortality Score (PRISM) score and determination of mortality risk factors in a tertiary pediatric intensive care unit. Clinics 2010;65(11):108792.

16. Aragao RCF, Albuquerque MFPM, Mello MJG, Ximenes 
RAA. Risk factors associated with death in children admitted to a paediatric intensive care unit. J Trop Pediatr. 2001;47:86-91.

17. Waiser AP, Chevret L, Essouri S, Durand P, Chevret S, Devictor D. Pneumococcal meningitis in a pediatric intensive care unit: Prognostic factors in a series of 49 children. PediatrCrit Care Med. 2005;6:568-72.

18. Martha VF, Garcia PC, Piva JP. Comparison of two prognostic scores (PRISM and PIM) at a pediatric intensive care unit.J Pediatr. 2005;81(3):259-64.

19. Bellad R, Rao S, Patil VD, Mahantshetti NS. Outcome of intensive care unit patients using pediatric risk of mortality (PRISM) score. IndianPediatr. 2009;46:1091-2.

20. El-Nawawy A. Evaluation of the outcome of patients admitted to the pediatric intensive care unit in Alexandria using the pediatric risk of mortality (PRISM) score. J Trop Pediatr. 2003;49:109-14.

21. Shann F. Are we doing a good job: PRISM, PIM and all that. Intensive Care Med2002; 28(2):105-7.

22. Khajeh A, Noori NM, Reisi M, Mohammadi M, Aliabad GM. Mortality Risk Prediction by Application of Pediatric Risk of Mortality Scoring System in Pediatric Intensive Care Unit. Iran J Pediatr2013;23(No 5): 546-50. 